\title{
Comparative Study of PCR-Based Approaches for the Genetic Characterization of Three Strains of Acidithiobacillus caldus Isolated from Different Sites in China
}

\author{
XUELING WU ${ }^{1}$, HONG DUAN $^{1}$, HONGWEI FAN ${ }^{1}$, ZHENZHEN ZHANG ${ }^{1}$ and LILI LIU ${ }^{1}$
}

\author{
${ }^{1}$ School of Minerals Processing and Bioengineering Key Laboratory of Biometallurgy of Ministry of Education \\ Central South University, Changsha, 410083, China
}

Submitted 28 December 2012, revised 6 August 2013, accepted 18 october 2013

\begin{abstract}
Comparative study of the genetic characteristics among three Acidithiobacillus caldus strains isolated from different typical environments in China was performed using a combination of molecular methods, namely sequencing analysis of PCR-amplified 16S rRNA genes and 16S-23S rRNA gene intergenic spacers (ITS), repetitive element PCR (rep-PCR), arbitrarily primed PCR (AP-PCR) fingerprinting and random amplified polymorphic DNA (RAPD). Both of the 16S rRNA gene and 16S-23S rRNA gene intergenic spacers sequences of the three strains exhibited small variations, with $99.9-100 \%, 99.7-100 \%$ identity respectively. In contrast, according to the analysis of bacterial diversity based on rep-PCR and AP-PCR fingerprinting, they produced highly discriminatory banding patterns, and the similarity values between them varied from $61.97 \%$ to $71.64 \%$. RAPD analysis showed that banding profiles of their genomic DNA exhibited obvious differences from each other with $53.44-75 \%$ similarity. These results suggested that in contrast to $16 \mathrm{~S}$ rRNA genes and $16 \mathrm{~S}-23 \mathrm{~S} \mathrm{rRNA}$ gene intergenic spacers sequencing analysis, rep-PCR, AP-PCR fingerprinting and RAPD analysis possessed higher discriminatory power in identifying these closely related strains. And they could be used as rapid and highly discriminatory typing techniques in studying bacterial diversity, especially in differentiating bacteria within Acidithiobacillus caldus.
\end{abstract}

Ke y w o rd s: Acidithiobacillus caldus, 16S rRNA gene, AP-PCR and Rep-PCR, ITS, RAPD

\section{Introduction}

Acidithiobacillus caldus (A. caldus) is a Gram-negative, strictly aerobic, rod-shaped bacterium which derives energy from the oxidation of reduced sulfur compounds. These bacteria appear to be found in acid mine drainage (AMD) and bioleaching reactors in moderately thermophilic environments (Baker and Banfield, 2003; Johnson and Hallberg, 2003; Zhou et al., 2009). It is considered to be the dominant sulfuroxidizing bacterium in the bioleaching of sulfide ores at $40^{\circ} \mathrm{C}-50^{\circ} \mathrm{C}$ (Foucher et al., 2003; Okibe et al., 2003). The main roles of A.caldus in bioleaching processes include: 1) removing the accumulated elemental sulfur on the surface that would otherwise retard the oxidation of ores. 2) producing organic growth factors that may stimulate heterotrophic and mixotrophic growth of bacteria. 3) producing surface-active agents to solubilize the $S^{0}$ (Dopson and Lindström, 1999; Watling, 2006).

In China, bacterial oxidation has been used to recover many metals such as gold, copper, uranium, nickel and manganese from ores. And applications of the bio-oxidation of copper, gold and uranium have been commercialized successfully. In order to control and optimize metal bioleaching, some quick and reliable methods are needed to identify and quantify single species in complex bioleaching communities. Various molecular methods, such as $16 \mathrm{~S}$ rRNA gene sequence analysis, DNA G+C content, DNA-DNA hybridization, DGGE (denaturing gradient gel electrophoresis), T-RFLP (terminal restriction fragment length polymorphism), RISA (ribosomal intergenic spacer analysis), PFGE (pulsed-field gel electrophoresis), RAPD (random amplification of polymorphic DNA), rep-PCR (repetitive extragenic palindromic polymerase chain reaction), FISH (fluorescent in situ hybridization) and real-time PCR, have been used to obtain a better understanding of the phylogenetic relationships of the interspecific and intraspecific strains (Mohapatra et al., 2011). These molecular typing techniques can generate differential DNA fingerprinting based on different principals, and hence differentiate different microorganisms.

However, little is known about the diversity of $\mathrm{A}$. cal$d u s$ strains involved in the bacterial oxidating process.

* Corresponding author: X. Wu, School of Minerals Processing and Bioengineering Key Laboratory of Biometallurgy of Ministry of Education, Central South University, Changsha, 410083, China. phone: +86-731-88836944; e-mail: wxlcsu@csu.edu.cn 
The aim of the present study was to characterize the genomic heterogeneity of $A$. caldus strains, using a combination of molecular systematic methods, namely sequencing analysis of PCR-amplified $16 \mathrm{~S}$ rRNA genes and 16S-23S rRNA gene intergenic spacers (ITS), repetitive element PCR (rep-PCR), arbitrarily primed PCR (AP-PCR) fingerprinting and random amplified polymorphic DNA (RAPD). In addition, this will provide useful information for researchers interested in microbial ecology and bioleaching as it not only describes the diversity of $A$. caldus within the species level systematically, which is rare in diversity research, but also targets on the dominant sulfur-oxidizing bacterium in the bioleaching of sulfide ores at $40^{\circ} \mathrm{C}-50^{\circ} \mathrm{C}$.

\section{Experimental}

\section{Materials and Methods}

Bacterial strains, media and culture conditions. This study was conducted with three strains of $A$. caldus recovered from two main geographical locations: acid mine drainage site and coal heap site. Among them, the A. caldus strains S-1, S-2 were isolated from samples from the coal heap drainage in Changsha, Hunan Province, China. While A.caldus strain D-1 was isolated from AMD of Dabaoshan Mineral Company in Guangdong Province, China. All of the A. caldus strains were cultivated using the typical $9 \mathrm{~K}$ medium $\left(\left(\mathrm{NH}_{4}\right)_{2} \mathrm{SO}_{4}\right.$ $3.0 \mathrm{~g} / \mathrm{l}, \mathrm{KCl} 0.1 \mathrm{~g} / \mathrm{l}, \mathrm{K}_{2} \mathrm{HPO}_{4} 0.5 \mathrm{~g} / \mathrm{l}, \mathrm{MgSO}_{4} \cdot 7 \mathrm{H}_{2} \mathrm{O} 0.5 \mathrm{~g} / \mathrm{l}$, $\left.\left.\mathrm{Ca}\left(\mathrm{NO}_{3}\right)_{2} 0.01 \mathrm{~g} / \mathrm{l}\right)\right)$ with $\mathrm{S}^{0}(10 \mathrm{~g} / \mathrm{l})$ and $\mathrm{pH}$ adjusted to 2.5 under the temperature of $45^{\circ} \mathrm{C}$.

DNA preparation. Bacterial cells were harvested by centrifugation at $7378 \times \mathrm{g}$ for $10 \mathrm{~min}$ and genomic DNAs of all bacteria were extracted using the TIANamp Bacteria DNA Kit (Tiangen Corporation Ltd. Beijing, China). DNA quantity was determined by spectrophotometry (Nanodrop Technologies, Rockland, DE). All DNAs were stored at $-20^{\circ} \mathrm{C}$ until being used.

Random amplified polymorphic DNA (RAPD). Twenty 10-mer primers from Operon Technologies Inc. (Alameda, CA, USA) were used for the PCR reactions (Table I). PCR reaction mixtures $(25 \mu \mathrm{l})$ contained $1 \mu \mathrm{l}$ (30 ng) of DNA, $2 \mu \mathrm{l}(10 \mu \mathrm{M})$ of the primer, 2.5 units $(0.5 \mu \mathrm{l})$ of Taq DNA Polymerase (Tiangen Corporation Ltd. Beijing, China), $2.5 \mu \mathrm{l}$ of $10 \times$ Tagbuffer, $2 \mu \mathrm{l}$

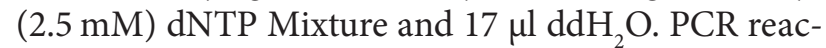
tion was performed in a thermocycler (Applied Biosystems Corporation, Ltd., USA). The amplification conditions were: an initial denaturation at $94^{\circ} \mathrm{C}$ for $5 \mathrm{~min}$, followed by 45 cycles of denaturation at $94^{\circ} \mathrm{C}$ for $1 \mathrm{~min}$, annealing at $37^{\circ} \mathrm{C}$ for $1 \mathrm{~min}$, extension at $72^{\circ} \mathrm{C}$ for $2 \mathrm{~min}$ and a final extension at $72^{\circ} \mathrm{C}$ for $10 \mathrm{~min}$.

Each amplification was done in triplicate or more and results were reproducible when DNA from differ-
Table I

Sequences of twenty oligonucleotide primers (Kit Operon) used in RAPD.

\begin{tabular}{|l|c|}
\hline \multicolumn{1}{|c|}{ Primers } & Sequence (5' to 3' $^{\text {) }}$ \\
\hline OPC-01 & TTCGAGCCAG \\
\hline OPC-02 & GTGAGGCGTC \\
\hline OPC-03 & GGGGGTCTTT \\
\hline OPC-04 & CCGCATCTAC \\
\hline OPC-05 & GATGACCGCC \\
\hline OPC-06 & GAACGGACTC \\
\hline OPC-07 & GTCCCGACGA \\
\hline OPC-08 & TGGACCGGTG \\
\hline OPC-09 & CTCACCGTCC \\
\hline OPC-10 & TGTCTGGGTG \\
\hline OPC-11 & AAAGCTGCGG \\
\hline OPC-12 & TGTCATCCCC \\
\hline OPC-13 & AAGCCTCGTC \\
\hline OPC-14 & TGCGTGCTTG \\
\hline OPC-15 & GACGGATCAG \\
\hline OPC-16 & CACACTCCAG \\
\hline OPC-17 & TTCCCCCCAG \\
\hline OPC-18 & TGAGTGGGTG \\
\hline OPC-19 & GTTGCCAGCC \\
\hline OPC-20 & ACTTCGCCAC \\
\hline
\end{tabular}

ent extractions of the same strain were used (Bergamo et al., 2004; Novo et al., 1996). The amplification products $(10 \mu \mathrm{l})$ were separated by electrophoresis on $1.5 \%$ agarose gel using $1 \times$ TAE buffer $(40 \mathrm{mM}$ Tris base, $20 \mathrm{mM}$ sodium acetate, $1.8 \mathrm{mM}$ EDTA, $\mathrm{pH}$ adjusted to 7.8 with glacial acetic acid) for $3 \mathrm{~h}$ at $40 \mathrm{~V}$. The gels were stained with ethidium bromide and photographed under UV. The $200 \mathrm{bp}$ DNA ladder (Tiangen Corporation Ltd. Beijing, China) was used as a size marker in all gels. The results were analyzed by comparing RAPD profiles on the basis of the presence (1) or absence (0) of each DNA band on the photographed agarose gels. Similarity analysis was performed using the DICE similarity coefficient in the NTSYS-PC software (Campos Paulino et al., 2001).

Rep-P CR and AP-P CR amplification. All PCR reactions were performed in a total volume of $25 \mu \mathrm{l}$ using 30-50 ng DNA, and carried out in duplicate using a thermocycler ( $\Lambda$ pplied Biosystems Corporation, Ltd., USA). BOX-PCR (based on primers targeting the highly conserved repetitive DNA sequences of the BOXA subunit of the BOX element) and ERIC-PCR (based on primers targeting the highly conserved enterobacterial repetitive intergenic consensus) were conducted to obtain the genomic fingerprinting of the bacteria described above. The rep primers were: for ERIC-PCR, ERIC-1R: 5'-ATGTAAGCTCCTGGGGATTCAC-3', ERIC-2: 5'-AAGTAAGTGACTGGGGTGAGCG-3', and 
for BOX-PCR, BOXA1R: 5'-CTACGGCAAGGCGACGCTGACG-3' (Versalovic et al., 1991; Versalovic et al., 1994). The reaction mixtures $(25 \mu \mathrm{l})$ contained $2.5 \mu \mathrm{l}(10 \mu \mathrm{M})$ of the each ERIC primer for ERIC-PCR and $5 \mu \mathrm{l}$ of BOX primer for BOX-PCR, 2.5 units $(0.5 \mu \mathrm{l})$ of Taq DNA Polymerase (Tiangen Corporation Ltd. Beijing, China), $2.5 \mu$ l of $10 \times$ Taq buffer, $2 \mu \mathrm{l}(2.5 \mathrm{mM})$ dNTP Mixture, $1 \mu \mathrm{l}$ DNA and $14 \mu \mathrm{ddH}_{2} \mathrm{O}$. The amplification conditions included an initial denaturation at $95^{\circ} \mathrm{C}$ for $7 \mathrm{~min}$, followed by 40 cycles of denaturation at $90^{\circ} \mathrm{C}$ for $30 \mathrm{~s}$, annealing at either $55^{\circ} \mathrm{C}$ (BOX-PCR) or $52^{\circ} \mathrm{C}$ (ERIC-PCR) for $30 \mathrm{~s}$, and amplification at $72^{\circ} \mathrm{C}$ for $8 \mathrm{~min}$, followed by a final extension at $72^{\circ} \mathrm{C}$ for $10 \mathrm{~min}$. PCR products were then examined through horizontal electrophoresis in $2 \%$ agarose gel containing ethidium bromide at $60 \mathrm{~V}$ for $5 \mathrm{~h}$ in $1 \times$ TAE buffer and photographed under UV.

In the AP-PCR amplification, primers M13 (5'-TTATGTAAAACGACGGCCAGT-3')(Jonas et al., 2000), BG2 (5'-TACATTCGAGGACCCCTAAGTG-3') (Van Belkum et al., 1993) and PJ118 (5'-TGTTCGTGCTGTTTCTG-3'), PJ108 (5’-GCTTATTCTTGACATCCA-3')(Lado and Yousef, 2003) were used. The PCR reaction mixtures $(25 \mu \mathrm{l})$ contained $1 \mu \mathrm{l} 30 \mathrm{ng}$ of DNA, $21(10 \mu \mathrm{M})$ of the primer, 2.5 units $(0.5 \mu \mathrm{l})$ of Taq DNA Polymerase (Tiangen Corporation Ltd. Beijing, China), $2.5 \mu \mathrm{l}$ of $10 \times$ Taq buffer, $2 \mu \mathrm{l}(2.5 \mathrm{mM}) \mathrm{dNTP}$ Mixture and $17 \mu \mathrm{lddH_{2 }}$ O. PCR was initiated with two cycles of low stringency, which included a denaturing step at $95^{\circ} \mathrm{C}$ for $1 \mathrm{~min}$, annealing of the primer at $36^{\circ} \mathrm{C}$ for $1 \mathrm{~min}$, and $2 \mathrm{~min}$ of extension at $72^{\circ} \mathrm{C}$. After the initial two cycles, 40 additional cycles were conducted with annealing of the primer at $55^{\circ} \mathrm{C}$. The reaction was terminated with a final extension cycle at $72^{\circ} \mathrm{C}$ for $10 \mathrm{~min}$. The amplification products $(12.5 \mu \mathrm{l})$ were separated by electrophoresis on $1.5 \%$ agarose $1 \times \mathrm{TAE}$ buffer gels. The gels were stained with ethidium bromide and photographed under UV. The $200 \mathrm{bp}$ DNA ladder (Tiangen Corporation Ltd. Beijing, China) was included in the gel to evaluate the molecular weight of the PCR products. Based on the banding patterns recognized on gel images, a binary (0-1) data sheet was set up. Similarity analysis was performed using the DICE similarity coefficient in the NTSYS-PC software (Campos Paulino et al., 2001).

Sequencing analysis of 16S rRNA genes and 16S$23 S$ rRNA gene intergenic spacers. For $16 \mathrm{~S}$ rRNA genes, the reverse primer was the universal $1387 \mathrm{R}$ (5'-GGGCGGWGTGTACAAGGC-3') and the forward primer was the universal 63F (5'-CAGGCCTAACACATGCAAGTC-3') (Marchesi et al., 1998). The primers 5'-GACTGGGGTGAAGTCGTAAC-3' and 5'-TGGCTGGGTTGCC-CCATTCGG-3' were used to amplify the 16S-23S rRNA gene intergenic spacers (Sagredo et al., 1992).
All PCR reactions were performed in a total volume of $25 \mu \mathrm{l}$. PCR reaction mixtures $1 \mu \mathrm{l}$ (30 ng) of DNA, $1 \mu \mathrm{l}(10 \mu \mathrm{M})$ of each primer, 2.5 units $(0.5 \mu \mathrm{l})$ of Taq DNA Polymerase (Tiangen Corporation Ltd. Beijing, China), $2.5 \mu$ l of $10 \times$ Taq buffer, $2 \mu \mathrm{l}(2.5 \mathrm{mM}) \mathrm{dNTP}$ Mixture and $171 \mathrm{ddH}_{2} \mathrm{O}$. PCR reaction was performed in a thermocycler (Applied Biosystems Corporation, Ltd., USA). The amplification conditions included an initial denaturation at $95^{\circ} \mathrm{C}$ for $5 \mathrm{~min}$, followed by 36 cycles denaturation at $94^{\circ} \mathrm{C}$ for $45 \mathrm{~s}$, annealing at $55^{\circ} \mathrm{C}$ for $45 \mathrm{~s}$, and amplification at $72^{\circ} \mathrm{C}$ for $90 \mathrm{~s}$, followed by a final extension at $72^{\circ} \mathrm{C}$ for $10 \mathrm{~min}$. The products of amplification were then examined through horizontal electrophoresis in $1.5 \%$ agarose gel containing ethidium bromide in $1 \times$ TAE buffer and photographed under UV. Amplimers of the expected size for the 16S rRNA gene (approximately $1.3 \mathrm{~kb}$ ) and 16S-23S rRNA gene intergenic spacers (approximately $600 \mathrm{bp}$ ) were excised from agarose gels and purified with the Universal DNA Purification Kit (Tiangen Corporation Ltd. Beijing, China) in accordance with the manufacturer's instructions. The purified PCR products were sequenced using an automatic ABI-PRISM3730 DNA analyzer (Applied Biosystems). The sequences of the $16 \mathrm{~S}-23 \mathrm{~S}$ rRNA gene intergenic spacers of the tested strains were submitted to the GenBank. Then these 16S rRNA genes and 16S-23S rRNA gene intergenic spacers sequences were aligned by using the CLUSTA L X program.

Nucleotide sequence accession numbers. The $16 \mathrm{~S}$ 23S rRNA gene intergenic spacers sequences determined in this work were deposited in the GenBank database under the accession numbers JX826622-JX826624.

\section{Results}

Analysis based on RAPD-PCR data. The genomic DNA of each strain used in this work was amplified using 20 different random primers. Eighteen of the primers tested produced a large number of specific and reproducible banding patterns revealing polymorphisms, whereas the other two primers (OPC-10, OPC14) were excluded from the data analysis due to the production of non-reproducible banding pattern. The size of the amplified products ranged from approximately 200 to 3400 bp. The RAPD profiles of the three A. cal$d u s$ strains were compared, and variation in the band profiles was observed for most primers (Fig. 1 presents only PCR results with primers OPC-5 and OPC-13). The similarity ratio among strains was calculated from the genomic DNA banding profiles generated by RAPD experiments. As shown in Table II, the highest similarity ratio of genomic DNA is between D-1 and S-1 (75\%), and the next is between S-2 and S-1 (59.26\%). The lowest similarity ratio is between S-2 and D-1 (53.44\%). 

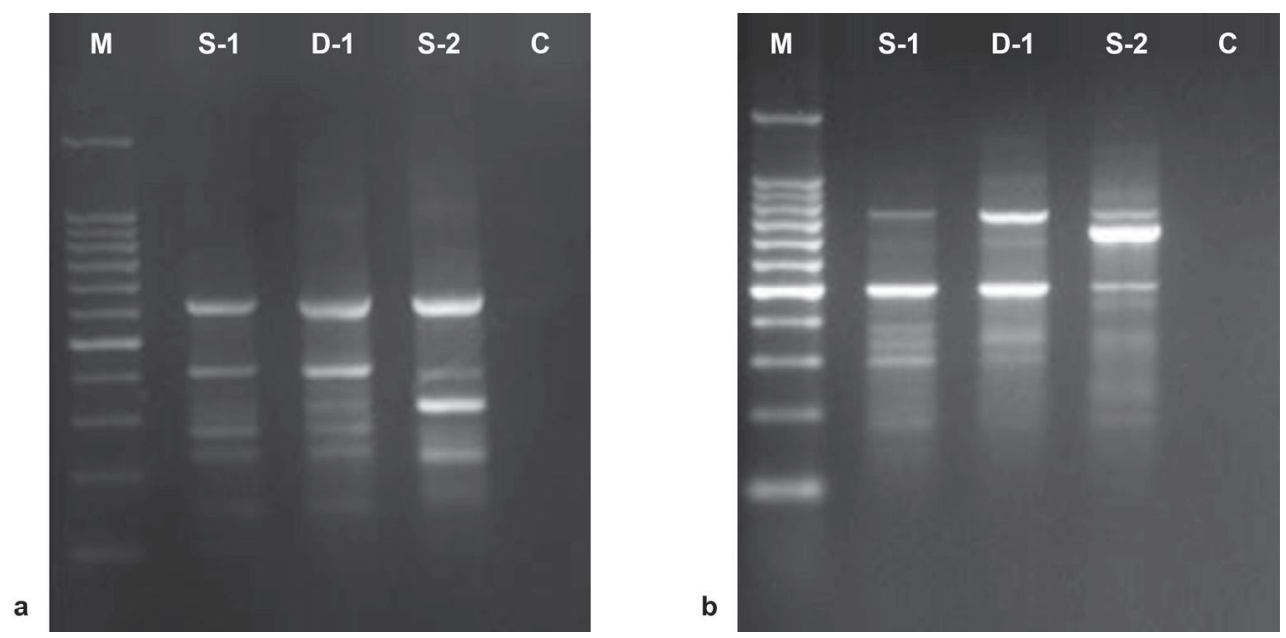

Fig. 1. RAPD genomic fingerprints of three tested A. caldus strains generated with OPC-5 (a) and OPC-13 (b) primer. M represents 200 bp DNA ladder. C represents negative control.
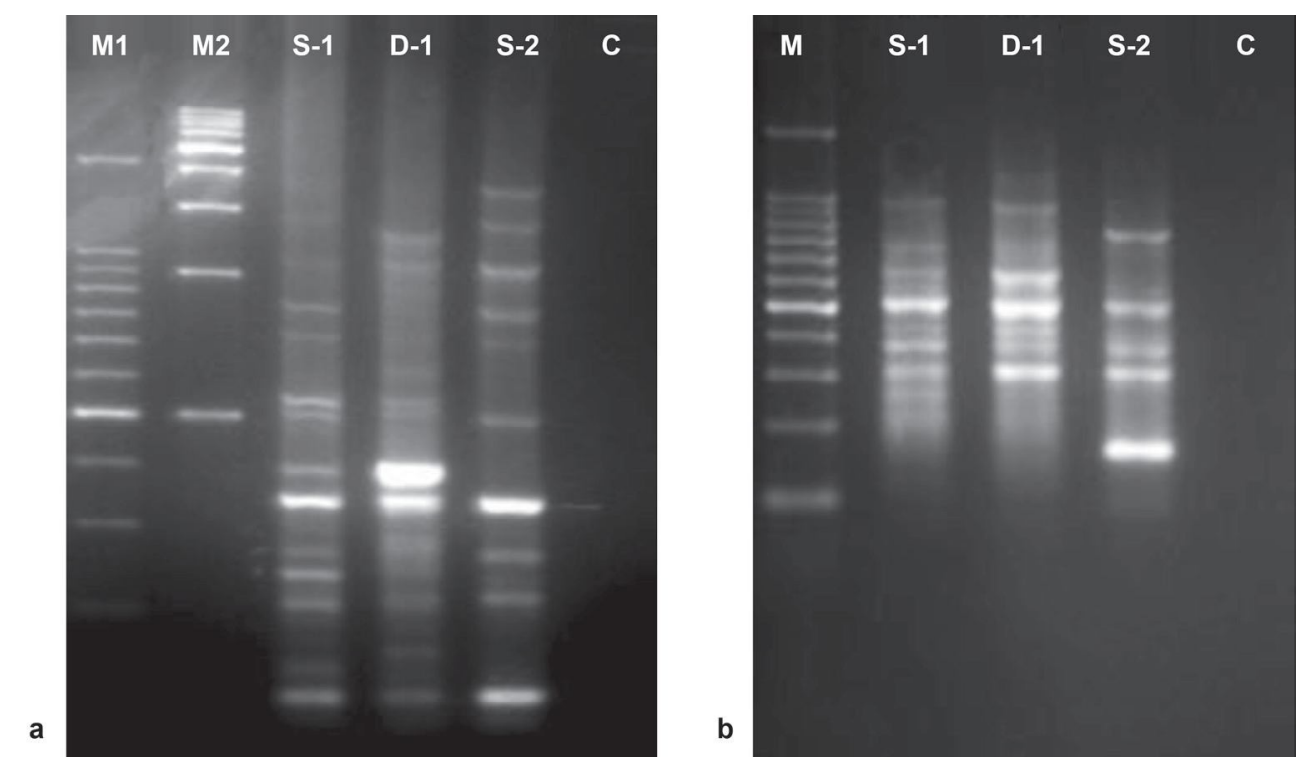

Fig. 2. a - DNA fingerprint patterns of A. caldus strains generated by ERIC-PCR. M1 represents 200-bp DNA ladder. M2 represents $1 \mathrm{~kb}$ DNA ladder. C represents negative control. $\mathrm{b}$ - Banding profiles of genomic DNA of three tested strains generated by AP-PCR with M13 primer. M represents 200-bp DNA ladder. C represents negative control.

Analysis of bacterial diversity based on rep-PCR and AP-PCR fingerprinting. Rep-PCR and AP-PCR experiments were performed to investigate the genotypic heterogeneity of the tested strains using the set of rep primers (BOX and ERIC) and AP primers (M13, PJ108, PJ118 and BG2). The results showed that the DNA banding profiles of the three strains exhibited obvious differences from each other. BOX-PCR yielded fingerprints with bands ranging from approximately 250 to $2000 \mathrm{bp}$, and the ERIC profiles encompassed bands ranging from approximately 200 to $2500 \mathrm{bp}$, whereas AP-PCR generated DNA fragments ranging in size from approximately 200 to $2100 \mathrm{bp}$. Almost every isolate yielded a unique and complex genomic fingerprint with each primer (Fig. 2 presents the results of
ERIC-PCR (a) and AP-PCR results with M13 primer (b)). The similarity ratio among them was calculated from the genomic DNA banding profiles generated by rep-PCR and AP-PCR experiments. As shown in Table II, the highest similarity ratio of genomic DNA is between S-2 and S-1 (71.64\%), and the next is between S-1 and D-1 (68.57\%). The lowest similarity ratio is between S-2 and D-1 (61.97\%).

Comparative analysis of $16 \mathrm{~S}$ rRNA genes and 16S23S rRNA gene intergenic spacers sequences. Amplifications and sequences of the $16 \mathrm{~S}$ rRNA genes were carried out with genomic DNA from the three A. caldus strains recovered from acid mine drainage or coal heap sites in China. According to our sequencing results, the nucleotide sequences of $16 \mathrm{~S}$ rRNA gene from these 
Table II

Similarity ratio of genomic DNA of the three tested strains determined by analysis of RAPD patterns and rep-PCR combined with AP-PCR fingerprinting.

\begin{tabular}{|l|c|c|c|c|c|c|}
\hline \multirow{2}{*}{ Strains } & \multicolumn{3}{|c|}{ RAPD } & \multicolumn{3}{c|}{ rep-PCR combined with AP-PCR } \\
\cline { 2 - 7 } & S-1 & D-1 & S-2 & S-1 & D-1 & S-2 \\
\hline S-1 & $100 \%$ & & & $100 \%$ & & \\
\hline D-1 & $75 \%$ & $100 \%$ & & $68.57 \%$ & $100 \%$ & \\
\hline S-2 & $59.26 \%$ & $53.44 \%$ & $100 \%$ & $71.64 \%$ & $61.97 \%$ & $100 \%$ \\
\hline
\end{tabular}

Table III

Overall similarity of 16S rRNA gene and 16S-23S rRNA gene intergenic spacers sequences between the three strains in the present study.

\begin{tabular}{|l|c|c|c|c|c|c|}
\hline \multirow{2}{*}{ Strains } & \multicolumn{3}{|c|}{ RAPD } & \multicolumn{3}{c|}{ rep-PCR combined with AP-PCR } \\
\cline { 2 - 7 } & S-1 & D-1 & S-2 & S-1 & D-1 & S-2 \\
\hline S-1 & $100 \%$ & & & $100 \%$ & & \\
\hline D-1 & $99.9 \%$ & $100 \%$ & & $100 \%$ & $100 \%$ & \\
\hline S-2 & $99.9 \%$ & $100 \%$ & $100 \%$ & $99.7 \%$ & $99.7 \%$ & $100 \%$ \\
\hline
\end{tabular}

Table IV

ITS and tRNA size (bp) based on the 16S-23S rRNA gene intergenic spacers sequence.

\begin{tabular}{|l|cccccc|c|}
\hline \multirow{2}{*}{ Strains } & \multicolumn{5}{|c|}{ Size (bp) } & \multirow{2}{*}{$\begin{array}{c}\text { GenBank } \\
\text { accession no }\end{array}$} \\
\cline { 2 - 7 } & ITS1 & ITS2 & ITS3 & tR $^{\text {NAI le }}$ & tRN $^{\text {AAl }} \mathrm{a}$ & Total & AF512808 \\
\hline DSM 85 ${ }^{84} \mathrm{~T}$ & 47 & 3 & 179 & 77 & 76 & 382 & JX826624 \\
\hline S-1 & 46 & 3 & 179 & 77 & 76 & 381 & JX \\
\hline D-1 & 46 & 3 & 179 & 77 & 76 & 381 & JX826623 \\
\hline S-2 & 46 & 3 & 179 & 77 & 76 & 381 & JX826622 \\
\hline
\end{tabular}

ITS and tRNA size of Acidithiobacillus caldus DSM $8584^{\mathrm{T}}$ derived from the 16S-23S rRNA gene intergenic spacers sequence in the NCBI database

three strains were $99.5-100 \%$ identical to that of the A. caldus strain DSM $8584^{\mathrm{T}}$ in GenBank (Z29975). The $16 \mathrm{~S}$ rRNA gene sequences of D-1 and S-2 were completely identical, while the $16 \mathrm{~S}$ rRNA gene sequence of S-1 was somewhat different from that of the other two strains with small variation. The similarity ratios among them calculated from the sequences of 16S rRNA gene were shown in Table III. Consequently, the variations of the 16S rRNA gene sequences are not sufficient to differentiate some closely related $A$. caldus strains.

At the same time, we have also determined the diversity of 16S-23S rRNA gene intergenic spacers sequences among the tested A. caldus strains. According to our sequencing results, the structure and organization of the 16S-23S rRNA gene intergenic spacers of the Chinese A. caldus isolates were consistent with the data of the type strain A.caldus DSM $8584^{\mathrm{T}}$ (Table IV). The 16S-23S rRNA gene intergenic spacers of all A. caldus isolates contain two highly conserved genes for tRNA ${ }^{\text {Ile }}$ and tRNA ${ }^{\text {Ala }}$, which split the ITS into three regions (ITS1, ITS2 and ITS3). Sequencing analysis showed that the nucleotide sequences of $16 \mathrm{~S}-23 \mathrm{~S}$
rRNA gene intergenic spacers from these three strains were $99.7-100 \%$ identical to that of the A. caldus strain DSM $8584^{\mathrm{T}}$ in GenBank (AF512808). The nucleotide sequences of the 16S-23S rRNA gene intergenic spacers from S- 1 and D-1 were completely identical to each other, while the 16S-23S rRNA gene intergenic spacers sequence of S-2 was somewhat different from that of the other two strains with only one nucleotide change (nucleotide 262, $\mathrm{C} \rightarrow \mathrm{T}$, Fig. 3). The similarity ratios among them calculated from the sequences of 16S-23S rRNA gene intergenic spacers are shown in Table III.

\section{Discussion}

Investigations have demonstrated that varied growth conditions, such as degree of pollution, substrate type and strength of toxic metal ions, can influence the structural changes in chromosomal DNA of Acidithiobacillus strains reflecting the genetic adaptation of the different ecotypes of Acidithiobacillus strains to different natural environments (Kondratyeva et al., 1995; Tupikina et al., 


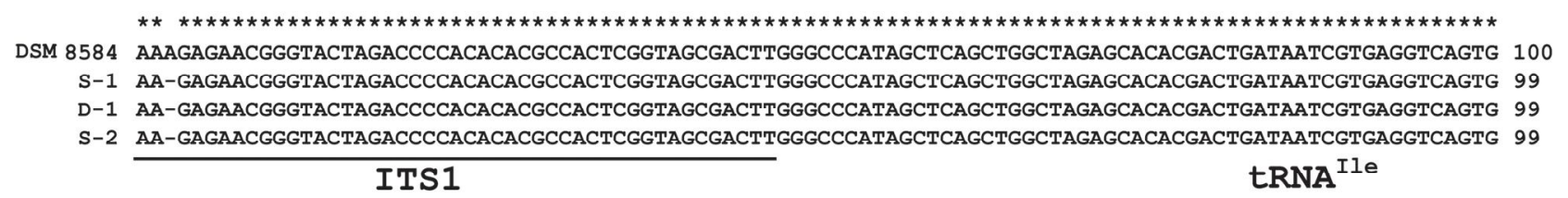
DSM 8584 GTTCGAGTCCACTTGGGCCCACCACATGGGGCTGTAGCTCAGTTGGGAGAGCACCGGCTTTGCAAGCCGGGGGTCACCGGTTCGAGACCGGTCAGCTCCA 200 S-1 GTTCGAGTCCACTTGGGCCACCACATGGGGCTGTAGCTCAGTTGGGAGAGCACCGGCTTTGCAAGCCGGGGGTCACCGGTTCGAGACCGGTCAGCTCCA 199 D-1 GTTCGAGTCCACTTGGGCCCACCACATGGGGCTGTAGCTCAGTTGGGAGAGCACCGGCTTTGCAAGCCGGGGGTCACCGGTTCGAGACCGGTCAGCTCCA 199 S-2 GTTCGAGTCCACTTGGGCCCACCACATGGGGCTGTAGCTCAGTTGGGAGAGCACCGGCTTTGCAAGCCGGGGGTCACCGGTTCGAGACCGGTCAGCTCCA 199 I $\overline{\mathrm{TS}} 2$ tRNA ${ }^{\mathrm{Ala}}$

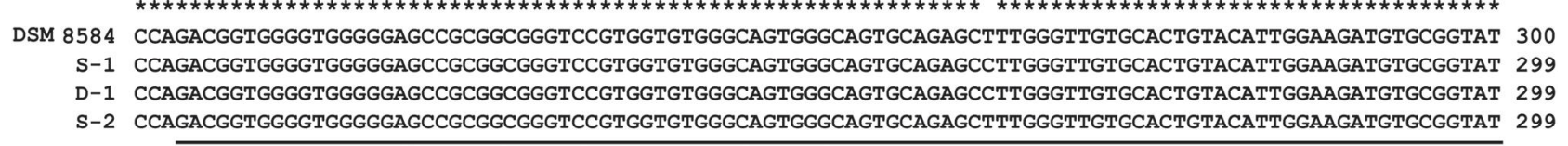
ITS3

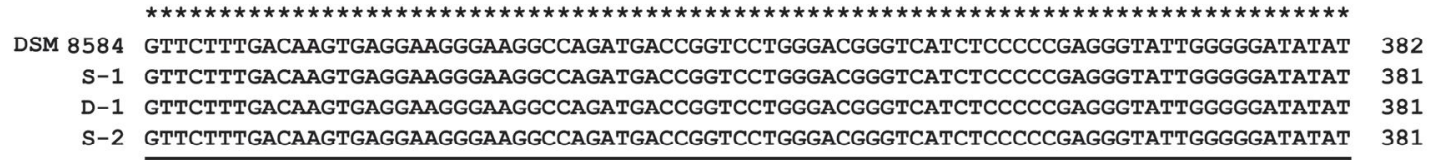

Fig. 3. Alignment of $16 \mathrm{~S}-23 \mathrm{~S}$ rRNA gene intergenic spacers sequences of the A. caldus strains. The $16 \mathrm{~S}-23 \mathrm{~S}$ rRNA gene intergenic spacers sequence of A. caldus DSM $8584^{\mathrm{T}}$ was derived from the NCBI database. The length of the ITS is indicated at the end of the sequences in nucleotides. Asterisks indicate identity, and spaces represent alignment gaps.

2006). Therefore, natural selection and genetic adaptation may be the reason why A. caldus strains occupying specific microbial niches in diverse environments are heterogeneous from each other.

In addition, previous studies have also demonstrated that most Acidithiobacillus strains isolated from various parts of the world contain a variety of insert sequences (IS) involved in the adaptation to changes in environmental conditions and in the regulation of the expression of biochemical pathways, which in turn result in changes to some phenotypic traits, including resistance to metal ions and the capacity for substrate oxidation (Rawlings, 2001; Kondrat'eva et al., 2005). Therefore, these mobile IS elements may be another cause resulting in the phenotypical and genotypical heterogeneity of Acidithiobacillus strains.

In the present work, the genomic heterogeneity of three A.caldus strains were analyzed and compared using a combination of molecular systematic methods, namely sequencing analysis of PCR-amplified 16S rRNA genes and 16S-23S rRNA gene intergenic spacers, repetitive element PCR, arbitrarily primed PCR fingerprinting and random amplified polymorphic DNA. Recently, polymorphism analysis of $16 \mathrm{~S}$ rRNA genes and 16S-23S rRNA gene intergenic spacers has been used extensively to identify the diversity analysis of microorganisms at the species level or above due to their high conservation (Gürtler and Stanisich, 1996; Gomes et al., 2010; Breuker et al., 2009). In addition, some studies have showed that in contrast to the 16S rRNA gene, polymorphism analysis of 16S-23S rRNA gene intergenic spacers exhibits considerable variation in structure and is more appropriate for studies at the intraspecies level (Ni et al., 2007; Darwish and Ismaiel, 2005). As described in this study, however, A. caldus strains from different econiches possessed only small variations in both with about $99.9-100 \%$ identity of $16 \mathrm{~S}$ rRNA gene, $99.7-100 \%$ identity of 16S-23S rRNA gene intergenic spacers respectively. It can be, therefore, suggested that some closely related strains may not be distinguishable on the $16 \mathrm{~S}$ rRNA gene and 16S-23S rRNA gene intergenic spacers level.

Rep-PCR and AP-PCR fingerprinting have been widely used to detect polymorphism in bacteria including Salmonella, Arthrobacter, Rhodococcus, and Pseudomonas (Liang et al., 2010; Albufera et al., 2009; Boulygina et al., 2009). They can differ in the rep-PCR and AP-PCR profiles which might lead to detect interspecies and intraspecies differences based on agarose patterns (De Meyer et al., 2011; Prieto et al., 2007; Emekdas et al., 2006). As described in this study, in the analysis of bacterial diversity based on rep-PCR and AP-PCR fingerprinting, almost every of the strains yielded a unique and complex genomic fingerprint with each primer. The three A. caldus strains exhibited obvious differences from each other with 61.97-71.64\% identity. These results, as well as others, clearly indicated that rep-PCR combined with AP-PCR fingerprinting could 
discriminate and differentiate closely related strains fastly and successfully (Ni et al., 2008; Xie et al., 2008; Ranjbar et al., 2007). Therefore rep-PCR combined with AP-PCR may be used as a quick and reliable alternative for establishing differences among strains of the same species as well as among different species.

Likewise, RAPD analysis has been widely used to differentiate bacterial strains among diverse species including Lactobacillus, Leuconostoc, and Acidithiobacillus (Omar et al. 2000; Ni et al., 2008; Abed and Hassan, 2009), and it has also been shown to be a powerful technique in detecting genomic diversity on the strain level (Martínez-Blanch etal., 2011; Waltenbury et al., 2005). In this study, RAPD analysis further showed that the genomic DNA banding profiles of the three strains exhibited obvious differences from each other, and the similarity between the three strains obtained in the RAPD patterns analysis ranged from $53.44 \%$ to $75 \%$. These results are in agreement with previous studies which reported that the similarity coefficients within A. ferrooxidans strains ranging from almost $0 \%$ to over 98\% (Novo et al., 1996). This study further proves that RAPD is a sensitive technique to assess strain variability among the same species (Waltenbury et al., 2005; Akbar et al., 2005).

In conclusion, in our study, A. caldus strains from different sources with a high degree of similarity $16 \mathrm{~S}$ rRNA gene and 16S-23S rRNA gene intergenic spacers sequences, could be distinguished on the basis of rep-PCR, AP-PCR fingerprinting and RAPD patterns. Therefore, rep-PCR, $\triangle \mathrm{P}$-PCR fingerprinting and RAPD-PCR profiles revealed a high degree of genomic diversity within A.caldus strains, and these methods could become important tools in the classification and identification of these bacteria. However, the accurate and reliable monitoring the genomic heterogeneity of microbes can only be achieved by integration of different molecular typing methods.

\section{Acknowledgements}

We acknowledge the support received from the National Basic Research Program (973 program) of P.R. China project 2010CB630901.

\section{Literature}

Abed K. and H.Z. Hassan. 2009. Genetic fingerprinting and relationships of some Corynebacterium isolates based on DNA polymorphism. Arab. J. Biotechnol. 12: 121-132.

Akbar T., K. Akhtar, M.A. Ghauri, M.A. Anwar, M. Rehman, M. Rehman, Y. Zafar and A.M. Khalid. 2005. Relationship among acidophilic bacteria from diverse environments as determined by randomly amplified polymorphic DNA analysis (RAPD). World. J. Microbiol. Biotechnol. 21: 645-648.

Albufera U., P. Bhugaloo-Vial, M.I. Issack and Y. JaufeerallyFakim. 2009. Molecular characterization of Salmonella isolates by REP-PCR and RAPD analysis. Infect. Genet. Evol. 9: 322-327.
Baker B.J. and J.F. Banfield. 2003. Microbial communities in acid mine drainage. FEMS Microbiol. Ecol. 44:139-152.

Bergamo R.F., M.T.M. Novo, R.V. Verissimo, L.C. Paulino, N.C. Stoppe, M.I.Z. Sato, G.P. Manfio, P.I. Prado, O. Garcia Ir and L.M.M. Ottoboni. 2004. Differentiation of Acidithiobacillus ferrooxidans and A. thiooxidans strains based on 16S-23S rDNA spacer polymorphism analysis. Res. Microbiol. 155: 559-567.

Boulygina E., A. Ignatov, S. Tsygankova, E. Korotkov and B. Kuznetsov. 2009. Interspecies relations between Bacillus thuringiensis strains studied by AP-PCR and sequence analysis of ribosomal operon regions. Microbiology 78: 703-710.

Breuker A., A. Blazejak, K. Bosecker and A. Schippers. 2009. Diversity of iron oxidizing bacteria from various sulfidic mine waste dumps. Adv. Mater. Res. 71: 47-50.

Campos Paulino L., R. Faria Bergamo, M.P. de Mello, O. Garcia, G.P. Manfio and L.M.M. Ottoboni. 2001. Molecular characterization of Acidithiobacillus ferrooxidans and A. thiooxidans strains isolated from mine wastes in Brazil. Anton. Leeuw. Int. J.G. 80: 65-75. Darwish A.M. and A.A. Ismaiel. 2005. Genetic diversity of Flavobacterium columnare examined by restriction fragment length polymorphism and sequencing of the 16S ribosomal RNA gene and the 16S-23S rDNA spacer. Mol. Cell. Probes. 19: 267-274.

De Meyer S.E., K. Van Hoorde, B. Vekeman, T. Braeckman and A. Willems. 2011. Genetic diversity of rhizobia associated with indigenous legumes in different regions of Flanders (Belgium). Soil. Biol. Biochem. 43: 2384-2396.

Dopson M. and E.B. Lindström. 1999. Potential role of Thiobacillus caldus in arsenopyrite bioleaching. Appl. Environ. Microbiol. 65: 36-40.

Emekdas G., G. Aslan, S. Tezcan, M.S. Serin, C. Yildiz, H. Ozturhan and R. Durmaz. 2006. Detection of the frequency, antimicrobial susceptibility, and genotypic discrimination of Aeromonas strains isolated from municipally treated tap water samples by cultivation and AP-PCR. Int. J. Food. Microbiol. 107: 310-314.

Foucher S., F. Battaglia-Brunet, P. d'Hugues, M. Clarens, J.J. Godon and D. Morin. 2003. Evolution of the bacterial population during the batch bioleaching of a cobaltiferous pyrite in a suspended-solids bubble column and comparison with a mechanically agitated reactor. Hydrometallurgy 71: 5-12.

Gürtler V. and V.A. Stanisich. 1996. New approaches to typing and identification of bacteria using the $16 \mathrm{~S}-23 \mathrm{~S}$ rDNA spacer region. Microbiology 142: 3-16.

Gomes F.C.O., C.L.C. Silva, C.R. Vianna, I.C.A. Lacerda, B.M. Borelli, Á.C. Nunes, G.R. Franco, M.M. Mourão and C.A. Rosa. 2010. Identification of lactic acid bacteria associated with traditional cachaça fermentations. Braz. J. Microbiol. 41: 486-492.

Johnson D.B. and K.B. Hallberg. 2003. The microbiology of acidic mine waters. Res Microbiol. 154: 466-473.

Jonas D., H.G.W. Meyer, P. Matthes, D. Hartung, B. Jahn, F.D. Daschner and B. Jansen. 2000. Comparative evaluation of three different genotyping methods for investigation of nosocomial outbreaks of Legionnaires' disease in hospitals. J. Clin. Microbiol. 38: 2284-2291.

Kondrat'eva T., V. Danilevich, S. Ageeva and G. Karavaiko. 2005. Identification of IS elements in Acidithiobacillus ferrooxidans strains grown in a medium with ferrous iron or adapted to elemental sulfur. Arch. Microbiol. 183: 401-410.

Kondratyeva T.F., L.N. Muntyan and G.I. Karavaiko. 1995. Zincand arsenic-resistant strains of Thiobacillus ferrooxidans have increased copy numbers of chromosomal resistance genes. Microbiology 141: 1157-1162.

Lado B.H. and A.E. Yousef. 2003. Selection and identification of a Listeria monocytogenes target strain for pulsed electric field process optimization. Appl. Environ. Microbiol. 69: 2223-2229 
Liang R., X. Wu, Q. Dai, D. Jin and Y. Wang. 2010. Genetic diversity of phthalic acid esters-degrading bacteria isolated from different geographical regions of China. Anton. Leeuw. Int. J. G. 97: 79-89.

Marchesi J.R., T. Sato, A.J. Weightman, T.A. Martin, J.C. Fry, S.J. Hiom and W.G. Wade. 1998. Design and evaluation of useful bacterium-specific PCR primers that amplify genes coding for bacterial 16S rRNA. Appl. Environ. Microbiol. 64: 795-799.

Martínez-Blanch J., G. Sánchez, E. Garay and R. Aznar. 2011. Evaluation of phenotypic and PCR-based approaches for routine analysis of Bacillus cereus group foodborne isolates. Anton. Leeuw. Int. J. G. 99: 697-709.

Mohapatra B.R., W. Douglas Gould, O. Dinardo and D.W. Koren. 2011. Tracking the prokaryotic diversity in acid mine drainage-contaminated environments: A review of molecular methods. Miner. Eng. 24: 709-718.

Ni Y.Q., K.Y. He, J.T. Bao, Y. Yang, D.S. Wan and H.Y. Li. 2008. Genomic and phenotypic heterogeneity of Acidithiobacillus spp. strains isolated from diverse habitats in China. FEMS Microbiol. Ecol. 64: 248-259.

Ni Y.Q., Y. Yang, J.T. Bao, K.Y. He and H.Y. Li. 2007. Inter-and intraspecific genomic variability of the 16S-23S intergenic spacer regions (ISR) in representatives of Acidithiobacillus thiooxidans and Acidithiobacillus ferrooxidans. FEMS Microbiol. Lett. 270: 58-66.

Novo M.T.M., A.P. De Souza, O. Garcia Jr and L.M.M. Ottoboni. 1996. RAPD Genomic Fingerprinting Differentiates Thiobacillus ferrooxidans Strains. Syst. Appl. Microbiol. 19: 91-95.

Okibe N., M. Gericke, K.B. Hallberg and D.B. Johnson. 2003. Enumeration and characterization of acidophilic microorganisms isolated from a pilot plant stirred-tank bioleaching operation. Appl. Environ. Microbiol. 69: 1936-1943.

Omar N.B., F. Ampe, M. Raimbault, J.-P. Guyot and P. Tailliez. 2000. Molecular Diversity of Lactic Acid Bacteria from Cassava Sour Starch (Colombia). Syst. Appl. Microbiol. 23: 285-291.

Prieto C., C. Jara, A. Mas and J. Romero. 2007. Application of molecular methods for analysing the distribution and diversity of acetic acid bacteria in Chilean vineyards. Int. J. Food. Microbiol. 115: 348-355.
Ranjbar R., N. Sadeghifard, A. Ahmadi, M. Izadi, J. Zaeimi-Yazdi, A. Ghasemi, M. Qurbanalizadgan and A. Rostamzad. 2007. Antimicrobial Susceptibility and AP-PCR Typing of Acinetobacter spp. Strains. Iran. J. Publ. Health. 36: 50-56.

Rawlings D.E. 2001. The molecular genetics of Thiobacillus ferrooxidans and other mesophilic, acidophilic, chemolithotrophic, iron- or sulfur-oxidizing bacteria. Hydrometallurgy 59: 187-201.

Sagredo B., E. Jedlicki and O. Orellana. 1992. Organization of the 16s-23s intergenic spacer region of the two rRNA operons from Thiobacillus ferrooxidans. Geomicrobiol. J. 10: 239-247.

Tupikina O.V., T.F. Kondrat'eva, V.D. Samorukova, V.A. Rassulov and G.I. Karavaiko. 2006. Pheno- and genotypic characteristics of Acidithiobacillus ferrooxidans strains as affected by physicochemical properties of pyrites. Hydrometallurgy 83: 255-262.

Van Belkum A., M. Struelens and W. Quint. 1993. Typing of Legionella pneumophila strains by polymerase chain reaction-mediated DNA fingerprinting. J. Clin. Microbiol. 31: 2198-2200.

Versalovic J., T. Koeuth and R. Lupski. 1991. Distribution of repetitive DNA sequences in eubacteria and application to finerpriting of bacterial enomes. Nucleic. Acids. Res. 19: 6823-6831.

Versalovic J., M. Schneider, F. De Bruijn and J.R. Lupski. 1994. Genomic fingerprinting of bacteria using repetitive sequence-based polymerase chain reaction. Methods. Mol. Cell. Biol. 5: 25-40.

Waltenbury D.R., L.G. Leduc and G.D. Ferroni. 2005. The use of RAPD genomic fingerprinting to study relatedness in strains of Acidithiobacillus ferrooxidans. J. Microbiol. Methods. 62: 103-112.

Watling H.R. 2006. The bioleaching of sulphide minerals with emphasis on copper sulphides - A review. Hydrometallurgy 84: 81-108.

Xie M., H.-q. Yin, Y. Liu, J. Liu and X.-d. Liu. 2008. Repetitive sequence based polymerase chain reaction to differentiate close bacteria strains in acidic sites. Trans. Nonferrous. Met. Soc. China. 18: 1392-1397.

Zhou H.-B., W.-M. Zeng, Z.-F. Yang, Y.-J. Xie and G.-Z. Qiu. 2009. Bioleaching of chalcopyrite concentrate by a moderately thermophilic culture in a stirred tank reactor. Bioresour. Technol. 100: 515-520. 